\title{
The Herzl Center for Israel Studies at Charles University
}

Founded in 2018 at Charles University in Prague, the Herzl Center for Israel Studies (HCIS) is an interdisciplinary teaching and research institution dedicated to the enhancement of knowledge and awareness about the modern State of Israel. The Center is the first academic institution in the Czech Republic that is entirely dedicated to the study of Israeli society, politics, and history. To contribute to the expanding field of Israel Studies, the HCIS focuses on the historical and contemporary links between Central Europe and Israel. Dr. Irena Kalhousová is the first head of the HCIS.

The Center was created as a joint project of two institutes of the Charles University Faculty of Social Sciences, the Institute of International Studies and the Institute of Political Studies, and the Israel Institute in Washington, D.C., an organization that supports Israel Studies at leading academic institutions in the U.S. and abroad. Under the patronage of the Rector of Charles University, the Center aims to attract students interested in several different disciplines. One of the main goals of the HCIS is to expand the number of courses offered by the Faculty of Social Sciences related to Israel and the contemporary Middle East. For the academic year 2020-21, the HCIS has prepared six B.A. and M.A. courses on Israeli politics and society, EU-Israel relations, relations between Central European countries and Israel, Israeli national security, and the Israeli-Arab conflict. Offering high-quality instruction is important to the HCIS. HCIS courses are taught by lecturers who are graduates of world-class Ph.D. programs and who are both expert in their fields and experienced teachers. For example, in the academic year 2020-21, the HCIS team will include two senior fellows, Dr. Emmanuelle Blanc from the London School of Economics and Dr. Rob Geist Pinfold from King's College London/Hebrew University Jerusalem, who will teach the courses on EU-Israel relations and Israel security strategy, respectively.

The HCIS seeks to foster closer academic cooperation between Charles University and Israeli, European, and U.S. institutions of higher education. In the academic year 2020-21, the HCIS plans to join with the Jagellonian University in Krakow and the Ludwig Maximilian University in Munich in relevant academic projects. As digital education has expanded because of the Covid-19 pandemic, the HCIS is actively preparing digital-based educational activities in cooperation with its international partners.

An important goal of the HCIS is supporting students and young scholars who are interested in Israel studies. The HCIS offers doctoral fellowships and promotes international and interdisciplinary research opportunities for Ph.D. students in Israel studies. The Center also provides travel grants for M.A. students that enable them to study and do research in Israel.

Lastly, the HCIS holds public events, discussions, and workshops related to Israel that are open to the general public. For example, as part of the Forum 2000 conference in Prague in 2019, the Center organized two debates on Israeli democracy and Israeli-Palestinian NGOs' involvement in projects meant to foster cooperation between Israelis and Palestinians. In spring 2020, the Center organized a debate on U.S. President Donald 
Trump's plan for Mideast peace, known as the "Deal of the Century." Furthermore, HCIS frequently provides commentary on events in Israel and the Middle East for the Czech media. ${ }^{1}$ By involving itself in the public space, the HCIS aims to promote and cultivate greater knowledge about Israel in the Czech Republic.

Irena Kalhousová

doi: $10.14712 / 23363231.2020 .14$

1 More information about Herzl Center publications and events is available at https://herzl.cuni .cz/HERZL-11.html as well as https://www.facebook.com/HerzlCenterPrague/. 